\author{
ZUZANA ČÍŽIKOVÁ* \\ Univerzita v Belehrade \\ Belehrad, Srbsko
}

\title{
K PORTRÉTU PROFESORA MICHALA FILIPA
}

\begin{abstract}
V príspevku sme sa pokúsili načrtnút portrét Michala Filipa (1915-1989), nestora vojvodinskej slovakistiky a to predovšetkým ako všestrannej osobnosti, s rozličnými záujmami a oblastami pôsobenia. Bol stredoškolským profesorom a vysokoškolským prednášatelom, divadelníkom, literárnym historikom a kritikom, prekladatelom, jazykovedcom, zostavovatelom čítaniek, editor i archivár. Osobitnú pozornost’ sme venovali pedagogickej činnosti prof. Filipa, najmä jeho prvým povojnovým čítankám pre slovenské stredné školy.
\end{abstract}

Klúčové slová: Michal Filip, slovakistika, kultúrna história, prvé povojnové slovenské čítanky

Profesor Michal Filip (1915-1989) patrí medzi významné osobnosti v slovenskom vojvodinskom kultúrnom a osvetovom živote $\mathrm{v}$ druhej polovici 20. storočia a najmä v prvom povojnovom desatročí, ked’ sa dávali organizačné základy v školstve, divadelníctve, vydavatel'stve a vôbec v celej kultúrnej činnosti; následne aj v 60 . rokoch, ked’ sa inštitucionálne zakladala a vzmáhala vojvodinská vysokoškolská slovakistika. Jeho pôsobenie a dielo stojí v základoch vojvodinskej slovakistiky a právom ho označujeme za jej nestora. Osobnosti a dielu Michala Filipa sa venovali viacerí autori; existuje niekolko obsiahlych i stručných prác (D. Dudok, 1985, 1989, M. Dudok, 1991, Týrová, 2015, Tarasjev, 2015, Myjavcová, 2015) a jedna pozoruhodná, však predovšetkým širšie publicisticky a populisticky zameraná publikácia pod názvom Sny a hviezdy profesora Michala Filipa (2015), ktorá vyšla pri príležitosti 100. výročia od jeho narodenia. Kniha je koncipovaná ako mozaika a výber z Filipovej tvorby a rozličných reflexií a spomienok na neho, čím sa vlastne načrtáva všestranný odborný, bádatel’sky, ale i ludský profil Filipovej osobnosti.

Michal Filip sa narodil 7. 1. 1915 v Starej Pazove, l’udovú školu skončil v rodisku a gymnázium v Báčskom Petrovci (1928-1936). Na Filozofic-

*z.cizikova@fil.bg.ac.rs 
kej fakulte Belehradskej univerzity vyštudoval srbčinu a staroslovienčinu a získal aj odborné znalosti z dejín juhoslovanských literatúr, teórie literatúry, histórie, českého a latinského jazyka (DMF19501010/7123). Učil sa u známych profesorov ako sú Belić, Košutić, Miletić, Bošković (Harpáň, 1989) a zrejme pre objektívne okolnosti (neisté vojnové časy) nezostal hned' pôsobit na fakulte. Diplom získal v roku 1941 (čo neskoršie musel nanovo písomne dokladat') a práve táto skutočnost̉ podla Andreja Tarasjeva (2005) ovplyvnila Filipovu profesionálnu kariérou a vedeckú činnost; aj napriek tomu, že mal široké slavistické vzdelanie a osobné charakterové predispozície na plodnú a bohatú vedeckú dráhu, celý pracovný vek bol lektorom a odborným pracovníkom, ktorému sa však, pre jeho erudovanost', systematickost', dôslednost', ba i minucióznu precíznost' natrvalo dostalo pomenovanie profesor. Počas vojny pracoval ako profesor na meštianke v S. Pazove (1942-1943), Kovačici a Bolovciach (1944). Potom pôsobil na gymnáziu v B. Petrovci (1944-1952), kde prednášal slovenčinu, srbčinu, dejepis a latinčinu (Pamätnica, 1969), obnovil činnoste žiackeho samovzdelávacieho krúžku Sládkovič, v ktorom aj sám pôsobil a ako mladík písal literárne práce a viac rokov bol aj vychovávatelom v chlapčenskej časti internátu. V roku 1952 nastúpil na miesto lektora českého a slovenského jazyka na Katedre východných a západných slovanských jazykov a literatúr Filozofickej (od roku 1960 Filologickej) fakulty v Belehrade. Ako externý vyšší odborný pracovník pôsobil aj na Filozofickej fakulte v Novom Sade (1961-1964) a potom ako riadny zamestnanec (1969-1975). V školskom roku 1970/1971 pobudol ako lektor srbochorvátčiny na Filozofickej fakulte Univerzity Komenského v Bratislave; na uvedenú fakultu ho natrvalo pozývali aj skôr (Harpáň, 1989). Na Katedru slavistiky FF BU sa vracia v roku 1975 na miesto lektora slovenského jazyka a dejín slovenského a českého jazyka, kde pôsobil do roku 1979. Do dôchodku odchádza z miesta odborného poradcu pre slovenský jazyk na Slovakistickom ústave FF v Novom Sade (1983). Zomrel v roku 1989 v Starej Pazove. Získal Cenu Spolku vojvodinských Slovakistov (1987) a Plaketu Slavistickej spoločnosti Srbska (1987) (DMF19780320/3711).

\section{Všestranná osobnost’ profesora Filipa}

K menu profesora Michala Filipa sa viaže celý rad záujmových oblastí a pritom $\mathrm{v}$ mnohých $\mathrm{z}$ nich vyoral prvé brázdy a trasoval tak cestu dalším kultúrnym a vedeckým pracovníkom. Bol úspešným pedagógom - vychoval mnohé generácie stredoškolákov a vysokoškolákov. Bol profesorom prvej povojnovej generácie žiakov, z ktorých vyrástli mnohé významné osobnosti nášho menšinového života ako sú $M$. Myjavcová, J. Kopčok, J. Makan, M. Týr a iní, mladší. Ich písané i ústne svedectvá svedčia o profesorovej velkej erudícii a sugestívnom prednese učiva, o nezištnej pomoci a ochote odo- 
vzdávat im vedomosti a vzbudzovat záujem o otázky jazyka a literatúry, čím v nemalej miere prispel k ich profesionálnemu formovaniu sa. V 50. rokoch 20. st. sa intenzívne venoval prekladu; prejavili sa tu jeho odborné znalosti z juhoslovanských literatúr a z vyštudovaného odboru ${ }^{1}$. K prekladom drámy sa dostal z dennej potreby nájst' vhodné dramatické texty pre inscenácie petrovských divadelných ochotníkov. Jeho velká tvorivá aktivita v ochotníckom divadle bola $\mathrm{v}$ znamení mladistvého zanietenia a entuziazmu a velkej lásky $\mathrm{k}$ tomuto druhu umenia. So stredoškolákmi a potom i v rámci novozaloženého Ústredného slovenského ochotníckeho divadla (1948), kde bol hlavným režisérom nacvičil a realizoval celý rad divadelných predstavení ${ }^{2}$. Kulminuje to v druhej polovici 40. rokov, ked' sa v jeho osobnosti zlúčili prekladatel', dramaturg, režisér, scénograf, kostýmograf, ba raz i herec. Divadlu sa venoval aj vedecky; výskumom divadelného ochotníctva položil základy divadelnej historiografie u nás (napr. v prácach $Z$ dejín slovenských ochotníckych divadiel vo Vojvodine, Devätdesiat rokov divadelného života $v$ Petrovci a iné). Vrcholom, ale zároveň i svojráznym koncom angažovania sa $\mathrm{v}$ ochotníckom divadle bola inscenácia VHV operety Pekná, nová, malovaná kolíska $v$ roku 1948. Aj ked’ išlo o významnú a vynikajúcu inscenáciu, nielen v zmysle inovačných scénických riešení a choreografie (na scéne bola vŕtaná studňa s vodou, svetelné efekty v podobe svojrázneho hologramu matky s dietatom) (Babiak - Filip, 1986, Filip, 1990), ale i opätovného uvedenia muzikálu na ochotnícku scénu, dobová kritika predstavenie ohodnotila ako „mysticko-idealistickú, bezmyšlienkovú hru” (König, 1948), nie celkom „na línii” a v duchu „budovania socializmu”: „Svojou povrchnostou, vulgárnostou, nevyriešovaním žiadnych problémov odputáva široké vrstvy od skutočnosti a napája človeka bolastnou romantikou, ktorá je cudzia človeku socializmu." (tamže). Vo svojich spomienkach na prof. Filipa M. Demák tiež uvádza: „Pán profesor sám v mladosti pocítil na vlastnej koži „konštruktívnu kritiku" straníckych kádrov /---/, ked" chcel "v čase budovania socializmu" na javisko postavit také spiatočnícke dielo, ako je Pekná, nová, malovaná kolíska." (2015). Filipova záluba v hudbe (nejde len o ludovú pieseň či tanec, ale i inscenácie operné, či operetné) svedčí o jeho vnímavom a senzitívnom prístupe k umeniu a v tomto prípade o snahe pozdvihnút ochotnícke divadlo na vyššiu úroveň a aj takto kultivovat dedinské divadelné obecenstvo. Môžeme to ocenit len s dodatočným časovým odstupom.

${ }^{1}$ Preložil drámy slovinského autora I. Cankara Král’na Betajnove (časopisecky, 1958) a Za blaho národa (v rukopise) (Týr, 2015, 66), I. Andrića Pokušenie a iné rozprávky (knižne, 1955), K. Čapka Rozprávky z jedného a druhého vrecka (knižne, 1955), B. Krefta Kalvária za dedinou (knižne, 1957) a iné.

${ }^{2}$ Na javisko postavil nasledovné hry: Vpád L. Leonova, Král na Betajnove I. Cankara, Zem, Záveje a operetu Pekná, nová, malovaná kolíska od VHV, Náš pán minister a Čaj u pána senátora I. Stodolu a iné. 
Pôsobenie prof. Filipa na Katedre východných a západných slovanských jazykov a literatúr Filozofickej fakulty v Belehrade má nesmierny význam pre rozvoj slovakistických štúdií na tomto pracovisku a potom i v Novom Sade; postupne sa popri češtine do študijného programu dostali aj slovakistické predmety; už koncom 60 . rokov slovenčina mala rovnoprávne zastúpenie vo vyučovacích predmetoch (Benková, 2015). Zo zachovanej korešpondencie profesora Krešimíra Geogijevića (1907-1975) vidíme, že Filipov príchod na katedru bol plánovaný už roku 1950. V liste z 25. októbra 1949 informuje prof. Filipa, že po neplánovanom odchode lektora českého jazyka Matejčeka spôsobeného politickou krízou medzi Juhosláviou a ČSR a po rozhovore s prof. Lalićom rozhodli sa na toto miesto pozvat práve prof. Filipa ako najkompetentnejšiu osobu (DMF19491029/3792). Vybavovanie tejto záležitosti sa však značne predížilo (na základe náznakov v listoch sú indície, že tunajší slovenskí predstavitelia moci robili obštrukcie a tento prechod prof. Filipa predlžovali). K realizácii prišlo v roku 1952 a v jeho pracovnej náplni bolo zabezpečovat’ výučbu češtiny a slovenčiny pre rusistov, svedčí o tom i zachovaný plán a program zo slovenského jazyka pre rusistov (zameraný na fonetiku a morfológiu, s krátkym prehladom dejín slovenského jazyka a pravopisom) (DMF0000grad/7263). Okrem toho prof. Filip mal aj kurz pod názvom Konfrontačná analýza srbochorvátskeho a ruského jazyka; cielom predmetu bolo „teoretické a praktické ovládanie podobností a rozdielov ruského a srbochorvátskeho jazykového systému a ich fungovanie v konkrétnej jazykovej praxi" (DMF0000konf/2087) na základe vtedajších výdobytkov konfrontačnej lingvistiky. V 60. rokoch sa do učebných plánov a programov dostávajú aj slovakistické predmety. Program pre slovenčinu ako hlavný predmet na skupine Slovenský jazyk a literatúra charakterizuje dôkladné prezentovanie hlavných jazykových rovín (fonetika, morfológia, tvaroslovie, syntax, lexikológia): „prístup jazykovému materiálu je deskriptívny s hlavným dôrazom na slovenskej jazykovej norme s osobitným dôrazom na srbochorvátsky jazyk" (DMF000konf/2087), predmet sa vyučoval 8 semestrov po 10 (1-5, 8 semester) a 14 hodín týždenne ( 6 a 7 semester). Tento konkrétny dokument, na základe odporúčanej literatúry lokalizujeme do 70. rokov 20. storočia, ked’ sa prof. Filip vrátil pôsobit na belehradskú slovakistiku (roku 1975). Z tohto obdobia datuje aj kurz Dejiny slovenského jazyka (s dialektológiou), resp. Dejín slovenského jazyka (DMF000prog/2082, DMF19790000/2080).

${ }^{3}$ V pozostalosti Michala Filipa v Ústrednom archíve Slovenskej evanjelickej a. v. cirkvi v Starej Pazove sa nachádzajú aj listy prof. K. Georgijevića, uložené pod číslom DMF19491029/3792. Pozostalost M. Filipa spracovala a nám ju aj sprístupnila pani Katarína Verešová, za čo jej srdečne dakujeme. 
Ešte pred nástupom na lektorské miesto prof. Filip bol v roku 1950 prijatý na Inštitút pre východné a západné slovanské jazyky a literatúry pri SAV v Belehrade ako externý spolupracovník s úlohou výskumu slovenských nárečí vo Vojvodine, na čo ho zvlášt podnecoval práve profesor K. Georgijević, ktorý už pred jeho príchodom na fakultu avizoval možnú tému jeho doktorskej dizertácie a spoluprácu na redakcii Česko-srbského slovníka. Filipova vedecká činnost̉ bola usmernená na výskum slovenskej vojvodinskej literatúry, kultúry a kultúrnej minulosti, ale aj na jazykovedný, presnejšie nárečový výskum, s čím súvisí aj jeho zberatel'ská činnoste (žial', velká čast jeho nárečového výskumu, ktorý mal byt podkladom pre dizertačnú prácu zostala verejnosti nedostupná, čast’ sa nachádza v jeho pozostalosti, jednu čast tvorí i hudobný materiál). Literárnej kritike sa venoval len ojedinele, svedčí o tom jediná recenzia zaradená do jeho knihy Štúdie a články (1989) v kapitole Pokus o literárnu kritiku o debute básnika Andreja Ferku. Adam Svetlík v rámci výskumu kritického čítania literatúry vojvodinských Slovákov Filipa zaraduje do prvej povojnovej generácie slovenských vojvodinských literárnych kritikov z akademického prostredia a pozoruje ho ako „kritický protiklad” Jána Kmeta. Ukazuje pritom na ich spoločné pozitivistické východisko, ale Filipa charakterizuje ako vedeckejšie zameraného a objektívnejšieho bádatela. „Tieto vlastnosti Filipovho tvorivého rukopisu boli iste na príčine jeho zjavnej inklinácie ku kultúrnohistorickým a jazykovým výskumom, ktoré svojou faktografickostou boli bližšie jeho tvorivej povahe ako príliš "metafyzické” literárne témy a problémy.” (Svetlík, 2015). Vo svojich literárnohistorických štúdiách sa Filip sústredil najmä na slovenských vojvodinských autorov z obdobia realizmu a moderny (J. Čajak, G. M. Petrovský, VHV), pritom spravidla najprv zohladňuje širšie historické a spoločensko-politické okolnosti života a tvorby autora a len potom to dáva do súvislostí s konkrétnym literárnym dielom. Tieto jeho výskumy neskoršie dostali primeraný priestor pri redigovaní a editorskej činnosti; na vydanie pripravil dva zväzky súborného diela Gustava Maršalla Petrovského a tvorbu VHV. Profesor Filip sa uvádza ako prvý významný hurbanológ z radov vojvodinských Slovákov, nielenže svojho rodáka VHV a jeho tvorbu, a aj genealógiu Hurbanovskej rodiny, dobre poznal, ale po jeho smrti zachránil a archivoval velkú čast̉ jeho pozostalosti (Babiak, 2000, Verešová, 2013), z čoho čast' daroval aj Slovenskej národnej knižnici v Martine. ${ }^{4}$ Zasvätene písal o Hurbanových realistických drámach v štúdii Hurbanove sedliacke

${ }^{4} \mathrm{~V}$ pozostalosti M. Filipa nachádzame dokumenty, kde sa uvádza, že prof. Filip z pozostalosti VHV na staropazovskej fare po roku 1956 Matici slovenskej daroval listy J. M. Hurbana, S. H. Vajanského, Š. Krčméryho a L. Podjavorinskej (DMF19651002/3524), však velká čast VHV pozostalosti sa dnes nachádza v Ústrednom archíve SEAVC v Starej Pazove. 
drámy (Filip, 1990) a podobne systematicky a dôkladne pripravil na vydanie čast' jeho rozsiahleho diela.

Prof. Filip spolupracoval s mnohými domácimi i zahraničnými vedcami a inštitúciami (Verešová, 2013), napríklad i s Maticou srbskou; pre jej vydanie Lexikónu juhoslovanských spisovatelov (Leksikon pisaca Jugoslavije I, II, Novi Sad, Matica Srpska 1972 a 1979) napísal heslá o slovenských spisovateloch a bol redaktorom jeho slovenskej časti. Vo svojich prácach sa venoval aj metodike slovenčiny, etymológii, slovensko-srbským vztahom, archívnemu výskumu, redakcii zborníkov a monografií a iné.

Filipovu zanietenost’a môžeme povedat aj zálubu v ozrejmovaní širších súvislostí sledovaného (kultúrneho, literárneho, historického, jazykového či genealogického) javu spojenú s altruizmom a príslovečnou skromnostou adekvátne a gnómický zhodnotil Miroslav Dudok, ked’ sa o profesorovi Filipovi vyjadril ako o „kráčajúcej encyklopédii”: „Nezištne sa so svojimi poznatkami a skúsenostami delil so svojimi žiakmi a študentmi a neraz jeho myšlienky zreli a uzreli svetlo dňa u iných." (1991)

\section{K Filipovým čítankám}

Už v medzivojnovom období sa vojvodinskí Slováci začali v celkovom kultúrnom a spoločenskom rozmachu organizovanejšie a intenzívnejšie starat’ o slovenské menšinové školstvo a v rámci toho aj zostavovat’ a vydávat čítanky pre slovenské ludové školy. V zmenenej spoločensko-politickej situácii po roku 1945 prichádza aj k reforme školstva a ako naliehavý problém sa pocitoval nedostatok učebníc. Na základe čulej korešpondencie profesora Filipa s vtedajšími predstavitelmi orgánov poverenými otázkami školstva ${ }^{5}$ uzavierame, že bol zapojený aj do koncipovania učebných osnov pre slovenské školy. Domnievame sa, že tesne po roku 1945 práve profesor Filip bol najpovolanejší a najkompetentnejší z radov našich vzdelancov na túto prácu a treba podotknút, že v nedostatku odbornej i krásnej literatúry. Postupne v prvej polovici 50. rokoch prof. Filip zostavil nasledovné ćítanky: Č́tanka pre prvú triedu slovenských stredných škôl (1951, dảej len Č1), Čítanka pre druhú triedu slovenských stredných škôl (1952, dảej len Č2), Čítanka pre tretiu triedu slovenských stredných škôl (1952, dalej len Č3), Čítanka pre štvrtú triedu slovenských stredných škôl (1954, dalej len Č4). Na rozdiel od medzivojnových čítaniek, ktoré boli široko koncipované ako čítanie z rozličných spoločenských a prírodných vied a kde predovšetkým dominovala didaktická funkcia (Hodoličová - Mladenović, 2016) v týchto čítankách sa zostavovatel', ak si odmyslíme publicistické texty s ideologickou a propagačnou funkciou, zameral predovšetkým na literárne texty. Tieto štyri čítanky

\footnotetext{
${ }^{5}$ Bola to Rada pre osvetu a kultúru GIONSAPV, ktorá všetky štyri čítanky aj schválila.
} 
sa koncepčne velmi podobajú; mali sa používat predovšetkým na hodinách slovenského jazyka a literatúry. Jednotlivé texty sa v nich opakujú, úryvky sú často z tých istých diel a zo strany zostavovatela preferovaných autorov (napr. zo slovenskej literatúry z obdobia romantizmu a realizmu, ojedinele sú tu autori z medzivojnového obdobia). To, čo aj dnes môžeme pozitívne zhodnotit je priestor, ktorý zostavovatel venoval ludovej tvorbe, čo jednak súvisí s koncepciou čítaniek prezentovat’ slovesnú tvorbu ako umelecké prejavy ludu od najstarších čias po súčasnost', ale zrejme i s dostupnostou prameňov, či afinitou samotného zostavovatela ku folklóru.

Na uvedené Filipove čítanky, z dnešného pohladu, môžeme mat všelijaké námietky (nedostatočná systematizácia textov, nedostatok návodu na prácu s textom, neprítomnost̉ kontextualizácie textu a iné), ale mienime, že sú čítanky a učebnice v mnohom odraz doby, v ktorej vznikli a že ich $\mathrm{v}$ tomto kontexte aj treba posudzovat'. Ako sme už naznačili, výber textov v mnohom podmieňovala spoločensko-politická situácia; aj do skúmaných čítankách sa dostala požiadavka vychovávat mladých v duchu novej ideológie. Najvýraznejšie je to v rámcujúcich častiach; na začiatku stoja texty s tematikou NOB-a, partizánskeho odboju, revolúcie, budovania socialistickej vlasti a pod. juhoslovanských (V. Nazor, B. Čopić), sovietskych (A. Konovov) a slovenských autorov (P. Jilemnický, F. Král, M. Krno, M. Lajčák) a apologetická a agitačná poézia o kulte osobnosti. V záverečných častiach sa nachádzajú vlastenecké básne a známe hymnické piesne, napr. Kto za pravdu horí K. Kuzmányho, Hej, Slovania S. Tomášika a iné.

Kompozícia čítaniek sleduje tematický princíp, čo čítanky robí žánrovo heterogénne a pôsobí dost̉ neusporiadane. Žánrové kritérium triedenia textov je dnes základnou premisou pri zostavovaní čítaniek a pomáha žiakom už od mladšieho školského veku postupne uchopit druhové a žánrové charakteristiky literárnych textov. Okrem velkej skupiny textov s dobovými témami, častá je téma vlastenectva, láska k matke, tematika zbojníctva a odboju, slobody, mladosti a pod. Práve na tejto tematickej zomknutosti zostavovatel nástojil: „Poradie článkov možno menit o dve-tri čísla, len neprehadzovat' z jedného okruhu do cyklu druhého, ktoré (cykly) nie sú v rukopise označené, ale z obsahu materiálu sa dajú lahko vycítit." (DMF19541012/3747). Z korešpondencie s vydavatelom zistujeme, že dáva návody ako postupovat pri sádzaní textu, aby sa nenarušila ich celistvost (nerozdelovat strofy na dve strany, nedávat názov na koniec strany a pod.) a zdôrazňuje tematické (v Č4 čiastočne i žánrové) zoskupovanie textov. Bol si vedomý potreby kultivovanej a kvalitnej učebnice: „Vôbec rečovej stránke a technickej úprave venujete väčšiu pozornost̉ ako (v ) čítankách predošlých. Čo sa docieli učebnicou, v ktorej sú tlačové chyby a iné nedopatrenia?" (tamže). 
Pri takomto zoradení textov prichádza do výrazu aj ich slabá lokalizácia. Lokalizovat text znamená „dat ho do súvisu s celkom, z ktorého je prebratý" (Dimitrijević, 1972 : 33, citované podla Francišković, preklad zo srbčiny Z.Č.). Úryvky tu fungujú ako uzavreté texty (svedčia o tom aj nové názvy úryvkov a tiež absencia bibliografických údajov, čo je príznačné najmä pre prvé dve čítanky), čo stažuje ich percepciu a následnú analýzu a interpretáciu, napríklad v Č1 pri úryvku Mata Lovraka pod názvom Detské ruky sa neuvádza, že ide o úryvok z románu Deti z velkej dediny. Pred úryvkom stojí krátka informácia, čo danej epizóde predchádzalo; takúto kontextualizáciu pri úryvkoch z väčších diel nachádzame potom čoraz častejšie. Kým v Č1 a Č2 sa literárnovedné pojmy vyskytujú len ojedinele a nesystematicky (napr. epiteton a komparácia v Č1, z verzológie v Č2), v d’alších dvoch čítankách je to už častejšie a funkčne zaradené (napr. archaizmus vysvetluje na príklade tvorby S. H. Vajanského, metaforu a prirovnanie na príkladoch z poézie J. Bottu, kontrast v poézii A. Sládkoviča). Lokalizácia textov v Č3 a Č4 je už pravidlom; uvádza sa odkial' je prebratý úryvok a po ňom nasleduje bio-bibliografická poznámka o autorovi s obrázkom, čo v predchádzajúcich čítankách bolo ojedinele. V jednotlivých skupinách textov vidiet' snahu aj žánrovo ich oddelit' (v obsahu Č4 bloky z ludovej slovesnosti majú osobitné tituly: Epické ludové piesne, Lyrické ludové piesne, L'udové rozprávky). Známe sú afinity Michala Filipa k ludovej tvorbe (na ludový nápev napísal partizánske piesne, zbieral a zapisoval pazovské ludové piesne), čo sa prejavilo aj v zostavovaní ćítaniek. Dominuje v nich ludová slovesnost; najviac je ludových piesní, ku ktorým odborne uvádza aj poznámku o pôvode, jazyku, estetických kvalitách. Osobitnú dlhšiu poznámku už v Č1 venuje ludovej rozprávke, povesti a báji, ktoré však interpretuje v duchu doby. V Č4 už dáva prehovorit odborníkovi; zaraduje sem dlhé state z pera folkloristu Jiřiho Horáka O ludovej epike slovenskej, Slovenská ludová lyrika a $O$ pôvode a vývoji ludových piesní. V tejto čítanke je každý text opatrený výkladom neznámych slov, čo značne prispievalo k percepcii umeleckých textov (predovšetkým ked išlo o staršie texty, z ktorých sú niektoré aj v češtine a bernolákovčine). Ani v jednej čítanke neexistujú metodické návody v podobe otázok a úloh na prácu s textom a aktiváciu žiaka, v tomto zmysle bolo používanie čítaniek v mnohom odkázané na metodickú zručnost' prednášatela, jeho kompetencie a „nové formy práce”, ako na to M. Filip upozorňuje už v 50. rokoch v článku Poznámky k rozvíjaniu gramotnosti u žiakov. Odkazuje tu na spätost' vyučovania jazyka, gramatiky, lexiky, slohu a pod. s literárnou výchovou: „Len čítaním literárnych diel žiak si nemohol osvojit primerané slovné bohatstvo a tvorivo ho použit vo vlastných ústnych a písomných prejavoch, lebo mnohým slovám a výrazom bez odbornej pomoci vyučujúceho ani nemohol správne rozumiet." (Filip, 1990) 
Aj napriek tomu, že mnohé texty v čítankách sú z dnešného hladiska anachronizmom, značná čast textov z tzv. literárneho dedičstva, ktoré Filip do čítaniek zaradil sa aj dnes nachádza v súčasných slovenských čítankách vo Vojvodine (napr. Smrt' Jánošíkova J. Bottu, Mor ho! S.Chalupku, Zuzanka Hráškovie P. O. Hviezdoslava a iné).

\section{Namiesto záveru}

Na dotvorenie portrétu profesora Michala Filipa je nevyhnutné preskúmat jeho celkovú bibliografiu, ale i bohatú pozostalost uloženú v ÚA SEVAC v jeho rodisku. Avizovaný druhý zväzok jeho Vybraných spisov tiež čaká na editora. Aj relatívne dobre preskúmané oblasti jeho pôsobenia (kultúrna história, literárne dejiny, jazykoveda) by sa mohli doplnit novými výskumnými poznatkami. Zaujímavé by bolo nahliadnut do zhromaždeného nárečového, či muzikologického materiálu. Osobitnú štúdiu by si žiadali tuná spomenuté programy, či uvedené čítanky, či skriptá Vybrané slovenské texty (Nový Sad, 1972), ktoré profesor využíval na svojich hodinách. V živote i diele profesora Michala Filipa sa ako v otvorenej knihe dá čítat osud i údel, povolanie i poslanie jedného výnimočného a zvláštneho človeka.

\section{PRAMENE}

Čítanka pre prvú triedu slovenských stredných škôl. Petrovec, Bratstvo - Jednota v Novom Sade : 1951.

Čítanka pre druhú triedu slovenských stredných škôl. Petrovec, Bratstvo - Jednota v Novom Sade : 1952.

Čítanka pre tretiu triedu slovenských stredných škôl. Petrovec, Bratstvo - Jednota v Novom Sade : 1952. 1954.

Čítanka pre štvrtú triedu slovenských stredných škôl. Petrovec, Kultúra :

Gradivo iz slovačkog jezika za rusiste. DMF000grad/7263. ÚA SEVAC v Starej Pazove.

Informacija o postavljanju M. Filipa za honorarnog saradnika Instituta za istočne i zapadne slovenske jezike i književnosti pri SANU, Beograd. DMF19501010/7123. ÚA SEVAC v Starej Pazove.

Listy prof. Krešimira Georgijevića. DMF19491029/3792. ÚA SEVAC v Starej Pazove.

List M. Filipa Vydavatel'skému podniku Kultúra. DMF19541012/3747. ÚA SEVAC v Starej Pazove.

List-gratuláciaprof.Dr.MilyStojnićprof.M. Filipovi.DMF19780320/3711. ÚA SEVAC v Starej Pazove. 
Programiz Slovačkogjezikakaoglavnog predmeta.DMF000konf/2087. ÚA SEVAC v Starej Pazove.

Program iz Istorije slovačkog jezika sa dijalektologijom. DMF000prog/2082. ÚA SEVAC v Starej Pazove.

\section{LITERATÚRA}

Babiak, M.: Jarné víchry nad Hurbanovou drámou. In.: Vladimír Hurban Vladimírov: Ked’ vejú jarné víchre..., Hra v troch dejstvách. Bratislava, ESA : 2000, s. 53-59.

Babiak, M.: Michal Filip - od mladosti venoval život osožnej práci. In.: Vzlet, 17, 1986, č. 7 , s. 4-5.

Benková, V.: L’udia, ktorých sme mali radi - profesor Michal Filip. In.: Sny a hviezdy profesora Michala Filipa. Stará Pazova - Báčsky Petrovec, Cirkevný zbor a Ústredný archív SEAVC - Slovenské vydavatel'ské centrum : 2015, s. 87-89.

Demák, M.: O jednej fotografii, o ohni, „čiernej vlne”, o rodokmeňoch Pazovčanov a o Mravcovi. In.: Sny a hviezdy profesora Michala Filipa. Stará Pazova - Báčsky Petrovec, Cirkevný zbor a Ústredný archív SEAVC - Slovenské vydavatelské centrum : 2015, s. 92-95.

Dudok, M.: Nevšedný slovakistický záber. Nový život, roč. 43, 1991, č. 3-4, s. 135-139.

Francišković, D.: Čitanka i metodološko oblikovanje programskog sadržaja. Dostupné na: metodickividici.ff.uns.ac.rs/index.php/MV/article/download/.../773. 28.7.2017.

Filip. M.: Štúdie a články. Nový Sad, Obzor : 1990, 209 str.

Harpáň, M.: Odišiel z našich radov. (Text, ktorý bol prečitaný na komemoračnom zhromaždení 30. mája 1989 na Filozofickej fakulte v Novom Sade). In.: Sny a hviezdy profesora Michala Filipa. Stará Pazova - Báčsky Petrovec, Cirkevný zbor a Ústredný archív SEAVC - Slovenské vydavatelské centrum : 2015, s. 116-117.

Hodolič, J. - Mladenović, G.: Prvi udžbenici na slovačkom jeziku slovačkih autora iz Vojvodine posle prvog svetskog rata. In.: Slavistika, XX, 2016, s. 365-370.

König, T.: Dve podoby „Peknej, novej, malovanej kolísky”. In.: Hlas ludu, roč. 5, 1948, č. 63 , s. 3 .

Pamätnica. 50 rokov slovenského gymnázia v Petrovci. Báčsky Petrovec, Slovenské gymnázium v Petrovci : 1969.

Svetlík, A.: Premeny literárnej kritiky vojvodinských Slovákov. Báčsky Petrovec, Slovenské vydavatelské centrum : 2015, 236 str.

Tarasjev, A.: Spomienka na profesora Michala Filipa (1915-1989). In.: Obzory. Príloha Hlasu ludu pre kultúru, vedu, umenie a literatúru. 22, č. 3/250, s. 5.

Týr, M.: Michal Filip ako prekladatel' Cankarových hier. In.: Sny a hviezdy profesora Michala Filipa. Stará Pazova - Báčsky Petrovec, Cirkevný zbor a Ústredný archív SEAVC - Slovenské vydavatel'ské centrum : 2015, s. 66-67.

Verešová, K.: Písomná pozostalost prof. Filipa je spracovaná. In. Hlas ludu, roč. 2013, č. 39, s. 21. 


\section{Zuzana Č́žiková}

\section{SKETCHES FOR A PORTRAIT OF PROFESSOR-MICHAL FILIP}

\section{Summary}

This paper drafts a portrait of a professor and the first language specialist of Slovak and Czech language of the Department of Slavic Studies at the Faculty of Philology, University of Belgrade - Michal Filip (1915-1989), the founder of Slovak studies in Vojvodina. Phrase 'walking encyclopedia' ( $M$. Dudok) best describes professor Filip's various interests and his immense knowledge. The paper covers all the field of his work (theatre, translation, linguistics, literary history, editing, etc.) and it particularly emphasizes his work in the field of pedagogy, or more precisely, the first reading textbooks for high school after the war.

Key words: Michal Filip, Slovak studies, cultural history, textbooks 